\title{
Serum C-Reactive Protein in Children with Liver Disease and Ascites
}

\author{
Gholamreza Kalvandi, ${ }^{1}$ Naser Honar, ${ }^{2}$ Bita Geramizadeh, ${ }^{3}$ Maryam Ataollahi, ${ }^{2}$ Asghar Rahmani, ${ }^{4}$ and \\ Hazhir Javaherizadeh ${ }^{5, *}$ \\ ${ }^{1}$ Department of Pediatrics, Ilam University of Medical Sciences, Ilam, IR Iran \\ ${ }^{2}$ Department of Pediatric Gastroenterology, Nemazee Teaching Hospital, Shiraz University of Medical Sciences, Shiraz, IR Iran \\ ${ }^{3}$ Department of Pathology, Nemazee Teaching Hospital, Shiraz University of Medical Sciences, Shiraz, IR Iran \\ ${ }^{4}$ Student Research Committee, Ilam University of Medical Sciences, Ilam, IR Iran \\ ${ }^{5}$ Nursing Research Center in Chronic Diseases and Department of Pediatric Gastroenterology, Ahvaz Jundishapur University of Medical Sciences, Ahvaz, IR Iran \\ "Corresponding author: Hazhir Javaherizadeh, Nursing Research Center in Chronic Diseases and Department of Pediatric Gastroenterology, Ahvaz Jundishapur University of \\ Medical Sciences, Abuzar Children’s Hospital, Ahvaz, IR Iran, E-mail: Hazhirja@yahoo.com, Javaherizadeh-h@ajums.ac.ir
}

Received 2016 May 05; Revised 2016 June 10; Accepted 2016 July 05.

\begin{abstract}
Background: The diagnosis of peritonitis as a complication of cirrhosis is an important clinical problem.

Objectives: The aim of this study was to evaluate serum C-reactive protein levels as a diagnostic factor for spontaneous bacterial peritonitis (SBP) in child patients with liver disease.

Methods: In this study, 150 children diagnosed with liver disease and ascites upon admission to Nemazee Teaching Hospital (Shiraz, Iran) were examined. Patients were divided into spontaneous bacterial peritonitis and sterile ascetic fluid groups according to the PMN count $\geq 250 / \mathrm{mm}^{3}$ in the ascetic fluids. Routine laboratory tests were conducted and quantitative C-reactive protein (CRP) levels were measured for all of the patients. Accuracy, sensitivity, and specificity of CRP was evaluated for diagnosis of SBP.

Results: Of 150 cirrhotic patients, 109 patients presented without SBP (52.29\% male, mean age: $5.02 \pm 4.49$ years) and 41 patients presented with SBP (51.21\% male, mean age: 4.71 years). Cell counts, protein levels, albumin levels, and lactate dehydrogenize (LDH) levels of the ascetic fluid and serum samples in the SBP group were higher than the rates for those without $\mathrm{SBP}(\mathrm{P}<0.05($. The mean $\pm \mathrm{SD}$ of CRP in the SBP group $(36.89 \pm 23.43)$ increased significantly compared to the rate among those without $\mathrm{SBP}(21.59 \pm 15.43, \mathrm{P}=$ 0.001). The percentages for sensitivity and specificity of CRP, the diagnosis of SBP based on the PMN count $\geq 250 / \mathrm{mm}^{3}$, and cultured ascites were $69.23 \%, 90.25 \%, 88.43 \%$, and $84.32 \%$, respectively. The areas under the curve of CRP for SBP based on the PMN count $\geq$ 250/ $\mathrm{mm}^{3}$ and cultured ascites was 0.94 (CI 95\%: 0.90 to 0.96) and 0.85 (CI 95\%: 0.84 to 0.92), respectively ( $\mathrm{P}<0.001$ ).

Conclusions: Our study showed that CRP is a marker with high sensitivity and specificity for the diagnosis of SBP in cirrhotic children.
\end{abstract}

Keywords: Cirrhosis, C-Reactive Protein, Peritonitis

\section{Background}

Spontaneous bacterial peritonitis (SBP) is defined as an infection of ascetic fluid without a proven intra-abdominal source $(1,2)$. SBP is a common and severe complication in cirrhotic patients (3), and is the major cause of mortality and morbidity among them (4). Bacterial infection due to complications such as hepatic encephalopathy or hepatic failure, disruption of homeostasis, and renal insufficiency are common causes of the increased morbidity and mortality rates in cirrhotic patients $(5,6)$. One of the required measures for SBP patients is rapid diagnosis of peritonitis for empirical antibiotic treatment $(7,8)$. Diagnosis of SBP is based on the number of ascetic fluid cells as polymorphonuclear cell count (PMN) $\geq 250 / \mathrm{mm}^{3}$ in ascetic fluid. Also, only 50 to $70 \%$ of a patient's positive cultures for ascetic fluid are generally reported (9-11). Due to limitations such as the time-consuming process for the diagnosis of peritonitis ascetic fluid and the lack of access to appropriate laboratory facilities, reports of negative cultures could be delayed $(12,13)$. Given these circumstances, numerous studies have been done on the available assessment techniques and rapid diagnosis of peritonitis.

It seems that some inflammatory cytokines can be used to determine the presence and severity of an inflammatory response and organ failure (14-16). The C-reactive protein is an acute phase protein that is produced predominantly by liver hepatocytes after stimulus by many cytokines and conditions such as infection or inflammation (17-20). The marker is one of the most common clinical and inflammatory indicators that can be measured in any laboratory $(21,22)$. A few studies have shown increased levels of this marker in cirrhotic patients $(1,2,23)$. For instance, in the 
study by Preto-Zamperlini et al., increased serum levels of CRP in children with SBP were demonstrated (24).

\section{Objectives}

We investigated the accuracy, sensitivity, and specificity of CRP compared to the PMN count of cultured ascetic fluid for the diagnosis of SBP in children.

\section{Methods}

This prospective study was conducted as a singlecenter cross-sectional cohort study during July 2013 to August 2014 in the department of pediatric gastroenterology in Nemazee Teaching Hospital, which is affiliated with Shiraz University of Medical Sciences, the major referral center in southern Iran. This study was approved by the ethics committee of Shiraz University of Medical Sciences, and all parents were asked to provide informed consent. All patients aged two months to 18 years, regardless of gender, who were admitted for liver disease and ascites were candidates for the sample for our study, and underwent abdominal paracentesis procedures for clinical suspicion of SBP.

The exclusion criteria were as follows: 1 , receiving antibiotics during the past week or outside the hospital for any reason; 2, history of abdominal surgery in the past month; 3, renal dysfunction; 4, secondary bacterial peritonitis; 5 , peritonitis carcinomatosis; 6 , pancreatic peritonitis; 7, malignancy, or 8 , tuberculosis. Children with other sources of infection were also not included, along with children with evidence of nephritic syndrome or heart failure. Based on the exclusion and inclusion criteria, 150 children with liver disease were included. After selection, patient paracentesis of ascetic fluid was performed on all patients. Cell blood count was determined, and serum samples were also obtained. Samples were sent to a specialized laboratory and subjected to laboratory, cytology, and bacteriology culture evaluation. WBC counts (Sysmex, USA), erythrocyte sedimentation rate (ESR), CRP levels, prothrombin time (PT), international normalized ratio (INR), serum total protein levels, serum albumin levels (Sigma Aldrich, St. Louis, USA), Alanine transaminase (ALT) levels, and Aspartate transaminase (AST) levels (Sigma Aldrich, St. Louis, USA) were determined for each case.

Diagnosis of SBP was based on PMN cell count $\geq$ $250 / \mathrm{mm}^{3}$ in ascetic fluid (25). In this study, serum was obtained from patients within the first hours of admission for measurement of CRP. Quantitative CRP was measured by the immunoturbidimetry method (Biorex, Antrim, UK). The cut off point for CRP in the study was $6 \mathrm{mg} / \mathrm{dL}$.
Data were expressed as means \pm SD for quantitative variables, and as frequencies for qualitative variables. The normality was continuously assessed with a KolmogorovSmirnov test. For the CRP marker compared to the PMN count by means of a positive culture test, sensitivity, specificity, positive predictive value (PPV), and negative predictive value (NPV) were calculated according to a standard formula. Also, the area under the curve (AUC) of the receiver operating characteristic (ROC) curves was applied to assess the predictive power of CRP. The data were assessed by simple linear regression analysis to determine the correlations between CRP values and other markers related to liver function, such as albumin, protein, PT, and bilirubin levels. A level of $\mathrm{P}<0.05$ was considered statistically significant. Statistical analysis of the data was performed using the SPSS 19) SPSS Inc., IL, Chicago, USA) software package.

This study was approved by the ethical committee of Shiraz University of Medical Sciences (No. EC-P-9363-6513).

\section{Results}

Basic characteristics of the patients are shown in Table 1. In total, information about 150 patients with cirrhosis of the liver was investigated; $72.7 \%$ of the patients presented without SBP, and $27.3 \%$ of patients were diagnosed with SBP. The most common symptoms in patients without SPB were abdominal pain (67.9\%) and abdominal distension (66.05\%). In patients with SBP, the most common clinical symptoms were also abdominal pain (70.7\%) and abdominal distension (58.5\%).

The etiology of cirrhosis revealed that the most common causes of cirrhosis were biliary atresia (29.3\%), neonatal hepatitis (19.26\%), and Wilson's disease (17.9\%) in patients without SBP. In patients with SPB, the most common causes of cirrhosis were also biliary atresia (31.7\%), neonatal hepatitis (24.4\%), and Wilson's disease (17.7\%).

Among the 150 cases, 17 cases had positive cultures for the following: E. coli $(n=7)$; Acinetobacter $(n=2)$; Klebsiella $(\mathrm{n}=2)$; Streptococcus pneumoniae $(\mathrm{n}=2)$; and Enterococ$\operatorname{cus}(\mathrm{n}=3)$.

The different results of the laboratory findings of cirrhotic patients without SBP and those with SBP are shown in Table 2. Evaluation of ascites fluid showed that the mean \pm SD of total cell counts in patients with SBP (1986.54 \pm 234.54) was significantly higher compared to the counts for patients without SBP $(725.46 \pm 134.35)(\mathrm{P}<0.0001)$. The means \pm SD of white blood cell (WBC) count and polymorph nuclear cell (PMN) count in patients with SBP were significantly higher than the counts for patients without $\operatorname{SBP}(\mathrm{P}<0.0001)$ (Table 2$)$.

The means and standard deviations of protein and albumin levels in patients with SBP were higher than the 
Table 1. Basic and Clinical Characteristic of Patients

\begin{tabular}{|c|c|c|c|}
\hline Basic Characteristic & Without SBP $(n=109)$ & With SBP $(n=41)$ & P Value \\
\hline Age, y, mean \pm SD & $5.02 \pm 4.49$ & $4.71 \pm 4.45$ & 0.646 \\
\hline Sex, No. (\%) & & & 0.881 \\
\hline Male & $57(52.30)$ & $22(53.66)$ & \\
\hline Female & $52(47.70)$ & $19(46.34)$ & \\
\hline \multicolumn{4}{|l|}{ Symptoms, No. (\%) } \\
\hline Vomiting & $31(28.44)$ & $13(31.70)$ & 0.689 \\
\hline Abdominal pain & $74(67.88)$ & $29(70.73)$ & 0.738 \\
\hline Abdominal distention & $72(66.05)$ & $24(58.53)$ & 0.393 \\
\hline Irritability & $27(24.77)$ & $8(19.51)$ & 0.498 \\
\hline Loss of consciousness & $14(12.84)$ & $6(14.63)$ & 0.774 \\
\hline Fever & $61(55.96)$ & $27(65.85)$ & 0.237 \\
\hline Poor feeding & $31(28.44)$ & $8(19.51)$ & 0.267 \\
\hline Etiology of Liver Disease, No. (\%) & & & 0.864 \\
\hline Idiopathic Neonatal Hepatitis (INH) & $21(19.26)$ & $10(24.39)$ & \\
\hline Congenital Hepatic Fibrosis (CHF) & $7(6.42)$ & 0 & \\
\hline Biliary Atresia & $32(29.35)$ & $13(31.70)$ & \\
\hline Tyrosinemia & $9(8.28)$ & $1(2.43)$ & \\
\hline Autoimmune Hepatitis (AIH) & $4(3.66)$ & 0 & \\
\hline Idiopathic Cirrhosis & $7(6.42)$ & $1(2.43)$ & \\
\hline Fulminant Hepatitis & $5(4.58)$ & $5(12.19)$ & \\
\hline Wilson's disease & $10(9.17)$ & $7(17.07)$ & \\
\hline Other & $14(12.84)$ & $4(9.75)$ & \\
\hline
\end{tabular}

corresponding rates in patients without $\mathrm{SBP}(\mathrm{P}<0.0001)$. Similar to the case with the other markers mentioned, the mean \pm SD of LDH in patients with SBP was higher than the corresponding rate in patients without SBP $(\mathrm{P}<0.0001)$. The means \pm SD of both WBC and PMN counts were higher in patients with SBP $(13587.6 \pm 240.4$ vs. $8029.4 \pm 332.3$, P $=0.005$, and $3024.5 \pm 265.4$ vs. $1766.54 \pm 435.3, \mathrm{P}=0.345$, respectively).

The means \pm SD of inflammatory markers such as CRP and ESR were significantly higher in patients with SBP in contrast to the rates for patients without $\mathrm{SBP}(\mathrm{P}<0.05)$ (Table 2).

Table 3 and Figure 1 show the area under the curve and the predictive values of CRP for the diagnosis of SBP in children with liver disease. The percentages for sensitivity and specificity of the CRP marker for SBP in cirrhotic patients according to the PMN count of ascetic fluid were $69 \%$ and $90.25 \%$, respectively (Table 3 ).

Figure 2 shows the relationship between the levels of CRP and total protein based on the presence (positive) or absence (negative) of SBP in cirrhotic patients. As shown in Figure 2, in both patients with and without SBP, the increased CRP levels were associated with increased total protein. However, this increase in patients with SBP showed higher severity than the increase in patients without SBP. Our results showed a significant correlation between total protein and CRP levels in children with and without $\operatorname{SBP}(\mathrm{P}=0.029, \mathrm{P}=0.006$, respectively $)$.

Figure 3 shows the relationship between albumin levels and CRP levels in patients with and without SBP. The results showed that in patients with SBP, increased levels of CRP were associated with increased albumin levels, which was significant $(\mathrm{P}=0.002)$. However, this result was not observed in patients without SBP; the levels of CRP albumin in patients without SBP decreased significantly $(\mathrm{P}=$ 0.013 ). The same results were revealed for bilirubin (Figure 4 ), in that with increased CRP in patients with SBP, bilirubin levels increased significantly $(\mathrm{P}=0.003)$, while in patients without SBP with increased levels of CRP, bilirubin levels decreased $(\mathrm{P}=0.011)$. The relationship between the 
Table 2. Laboratory Data of Patients

\begin{tabular}{|c|c|c|c|}
\hline Data & Without SBP $(n=109)$ & With SBP $(n=41)$ & P Value (Unpaired t-Test) \\
\hline \multicolumn{4}{|l|}{ Ascetic fluid } \\
\hline WBC count, $\mu \mathrm{L}$ & $170.54 \pm 87.65$ & $1114.5 \pm 234.3$ & $<0.0001$ \\
\hline PMN count, $\mu \mathrm{L}$ & $46.56 \pm 34.23$ & $945.3 \pm 342.4$ & $<0.0001$ \\
\hline Protein, g/dL & $1.78 \pm 1.17$ & $2.6 \pm 1.26$ & $<0.0001$ \\
\hline Albumin, $\mathrm{g} / \mathrm{dL}$ & $0.79 \pm 0.43$ & $1.3 \pm 0.8$ & $<0.0001$ \\
\hline Sugar & $81.43 \pm 25.3$ & $79.9 \pm 23.7$ & 0.654 \\
\hline LDH, U/L & $160.65 \pm 76.4$ & $398.54 \pm 87.6$ & $<0.0001$ \\
\hline \multicolumn{4}{|l|}{ Serum } \\
\hline $\mathrm{WBC}, \mu \mathrm{L}$ & $8029.4 \pm 332.3$ & $13587.6 \pm 240.4$ & 0.005 \\
\hline PMN, $\mu \mathrm{L}$ & $1766.54 \pm 435.32$ & $3024.5 \pm 265.4$ & 0.345 \\
\hline ALT, IU/L & $151.86 \pm 34.3$ & $177.2 \pm 34.5$ & 0.523 \\
\hline AST, IU/L & $264.5 \pm 65.4$ & $186.5 \pm 34.2$ & 0.240 \\
\hline Protein, $\mathrm{g} / \mathrm{dL}$ & $4.9 \pm 1.2$ & $4.9 \pm 2.3$ & 0.859 \\
\hline Albumin, $\mathrm{g} / \mathrm{dL}$ & $3.07 \pm 1.23$ & $3.23 \pm 1.3$ & 0.310 \\
\hline $\operatorname{PT}(s)$ & $17.29 \pm 10.43$ & $17.86 \pm 23.2$ & 0.738 \\
\hline INR & $19.66 \pm 12.54$ & $14.06 \pm 12.2$ & 0.366 \\
\hline Total bilirubin, $\mu \mathrm{mol} / \mathrm{L}$ & $132.3 \pm 23.2$ & $120.6 \pm 23.4$ & 0.382 \\
\hline $\mathrm{ESR}, \mathrm{mm} / \mathrm{h}$ & $20.14 \pm 7.65$ & $32.8 \pm 23.2$ & 0.002 \\
\hline $\mathrm{CRP}, \mathrm{mg} / \mathrm{L}$ & $21.59 \pm 15.43$ & $36.9 \pm 23.4$ & 0.001 \\
\hline
\end{tabular}

Abbreviations: ALP, Alkaline phosphates; ALT, Alanine aminotransferase; AST, Aspartate aminotransferase; CRP, C-reactive protein; ESR, estimated sedimentation rate; INR: international normalization rate; LDH: lactate dehydrogenate; PT: prothrombin time; PMN: polymorphonuclear cell; WBC: White blood cell.

Table 3. Areas Under the Curve and Predictive Values of C-Reactive Protein for SBP Patients With Liver Disease

\begin{tabular}{lccccccc}
\hline & Sen & Spe & PPV & NPV & Accuracy & AUC (CI) \\
\hline PMN $\geq \mathbf{2 5 0} / \mathbf{m m}^{3}$ & 69.23 & 90.25 & 88.65 & 89.54 & 89.33 & $0.94(0.90-0.96)$ & $<0.0001$ \\
Positive Culture Ascetic & 88.43 & 84.32 & 85.48 & 90.32 & 85.63 & $0.85(0.84-0.92)$ & $<0.0001$ \\
\hline
\end{tabular}

Abbreviations: AUC, area under curve; NPV, negative predictive value; PPV, positive predictive value; Sen, sensitivity; Spe, specificity.

${ }^{\mathrm{a}}$ Values are expressed as \%.

CRP levels with PT among the patients is shown in Figure 5. Increased protein level was associated with significantly increased PT $(\mathrm{P}=0.006)$. However, in patients with SBP, PT did not change significantly according to the level of CRP changes $(\mathrm{P}=0.697)$.

\section{Discussion}

SBP is a frequent and serious complication in cirrhotic patients that is associated with high in-hospital mortality rates of $20 \%-30 \%$, poor prognosis, and recurrence of over $70 \%$ in the first year of life. Early antibiotic treatment can reduce the mortality and morbidity of SBP, which requires performance and rapid diagnostic tests (26). Although extensive studies have been conducted for laboratory testing efficiency and various markers for the diagnosis of SBP (24, 26), the first report on the highly significant correlation between CRP and SBP was only published recently (24).

In the study by Preto-Zamperlini et al. on 90 children with chronic liver disease, Streptococcus pneumoniae was the most cultured organism (24). In our study, E. coli was the most frequently cultured organism. The serum WBC counts were significantly higher in the SBP group compared to the counts for patients without SBP. This finding was similar to the results of Preto-Zamperlini et al.'s study (24). Measurement of CRP in cirrhotic patients determined 


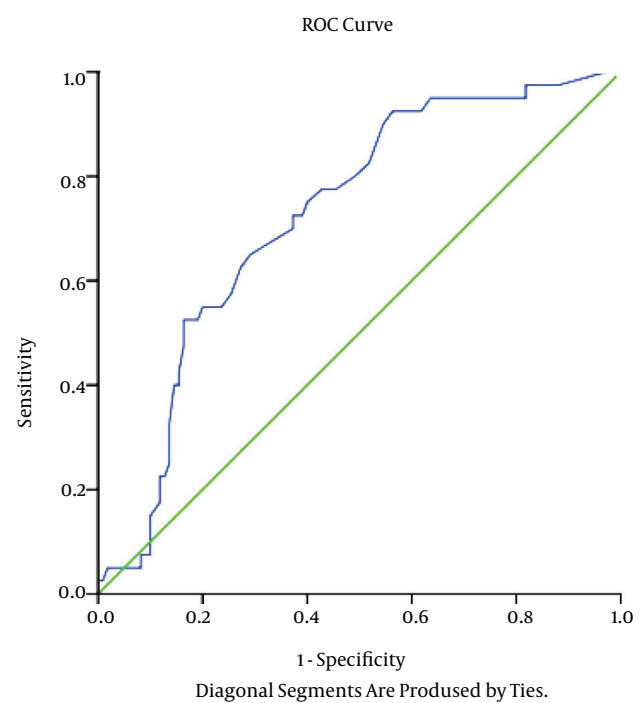

Figure 1. ROC Curve of Predictive Value of CRP in the Diagnosis of SBP

that serum CRP levels were significantly higher in patients with SBP compared to patients without SBP. In the study by Preto-Zamperlini et al., the CRP level was significantly higher in cases with SBP than in cases without SBP (24). In the study by Yuan et al., it was concluded that CRP is a better marker than WBC count for diagnosis of patients with chronic hepatitis B and SPB (27).

ESR was significantly higher in patients with SBP com-

Figure 2. The Relationship Between CRP Levels and Total Protein in Cirrhotic Child Patients According to SBP

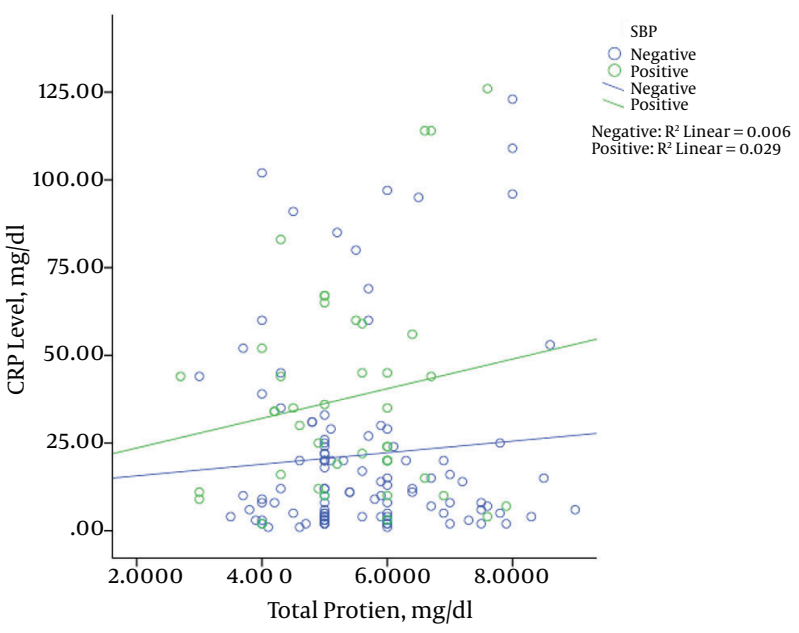

CRP, C-Reactive protein; SBP, Spontaneous bacterial peritonitis.
Figure 3. The Relationship Between CRP Levels and Albumin in Children With Liver Disease According to SBP

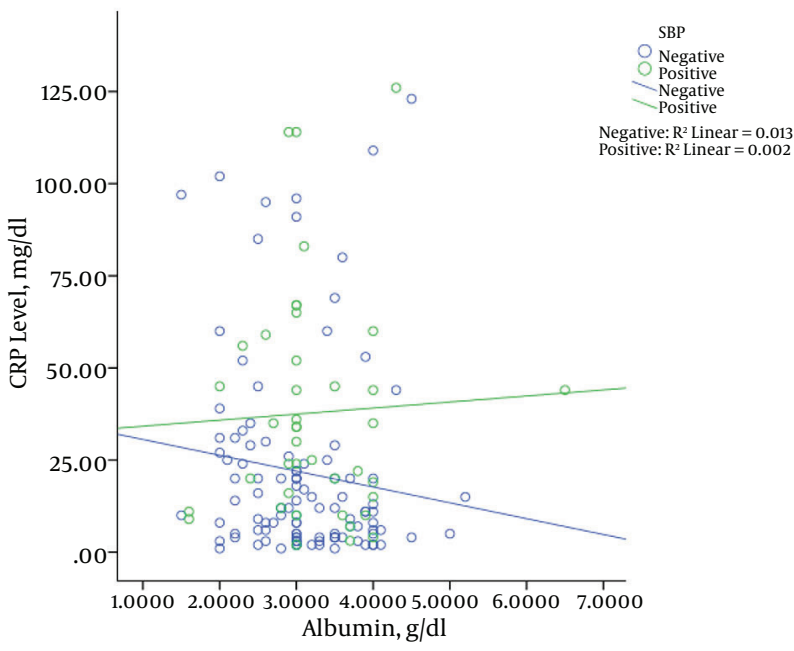

CRP, C-reactive protein; SBP, spontaneous bacterial peritonitis.

pared to patients without SBP. In another study by Viallon et al., the authors reported that CRP is significantly higher in adult cirrhotic patients with SBP compared to those that had sterile ascites fluid (28).

The serum total bilirubin levels were not significantly different between children with SBP and those without SBP. This finding was similar to those of other studies $(24,29)$.

In our study, albumin levels were significantly higher

Figure 4. Relationship Between CRP Levels and Total Bilirubin in Child Patients According to SBP

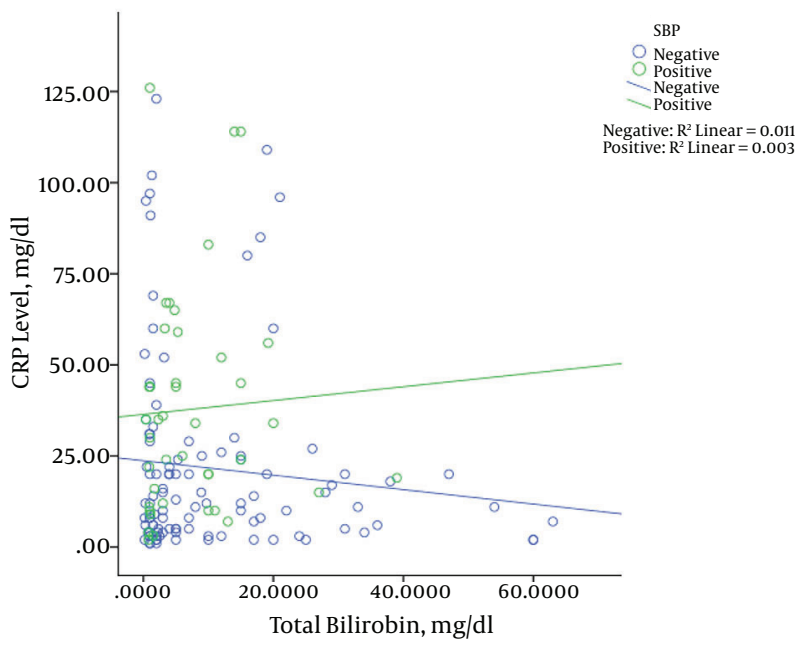

CRP, C-reactive protein; SBP, Spontaneous bacterial peritonitis. 
Figure 5. Relationship Between CRP Levels and Prothrombin Time in Child Patients According to SBP

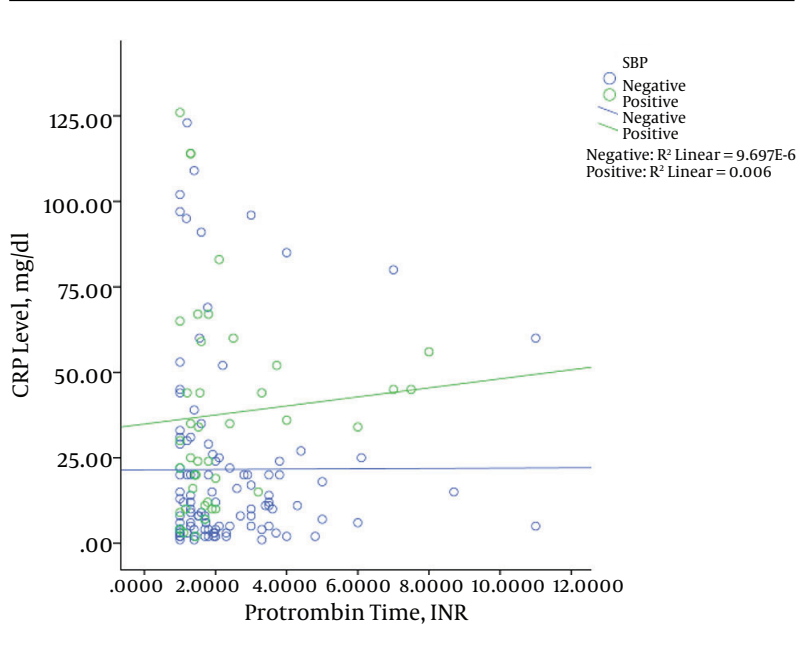

CRP, C-reactive protein; SBP, Spontaneous bacterial peritonitis.

in the SBP group compared to the non-SBP group. In contrast to our study, albumin levels were significantly higher in the non-SBP group compared to SBP group in the study by Preto-Zamperlini et al. (24). In Vieira et al.'s study, no significant difference was found between SBP patients and those with non-SBP ascites (30). This difference may be due to the difference in sample size or the histories of albumin infusion.

In our study, no significant difference was found between the two groups in terms of PT and INR. This result is similar to the study by Vieira et al., who reported that these markers in patients with and without SBP were not significantly different (30). In contrast to the above study, a significant difference was found in the study by PretoZamperlini et al. (24). In another study, CRP was a significant indicator of infection in hospitalized children with cirrhosis (31). The difference between the severity of liver disease in these studies may be the cause of these differences.

The results of our study showed no significant difference regarding the age and sex of the patients with and without SBP.

As mentioned above, serum WBC count, ESR, and CRP may be good indicators of SBP in children with liver disease. However, further studies are required in this field because most of the available studies have been conducted on adult patients.

\subsection{Limitation}

The main limitation is the single-center focus of the study. Another limitation is the lack of serial measurement of CRP and the lack of finding a correlation between CRP and prognosis and recurrence of SBP. The small sample size of children with SBP is another limitation. Also, some selection bias could not be avoided.

\section{Acknowledgments}

The data used in this study was obtained from the fellowship thesis of Dr. Gholamreza Kalvandi (No. CT-P-6513). Authors also acknowledge the laboratory personnel of Nemazee Teaching Hospital for their assistance.

\section{Footnotes}

Authors' Contribution: Gholamreza Kalvandi, proposal writing and data collection; Bita Geramizadeh, laboratory analysis, quality control, and supervisor of thesis; Naser Honar, main idea and supervisor of thesis; Maryam Ataollahi, data collection and revision of manuscript; Asghar Rahmani, writing of the draft and data analysis; Hazhir Javaherizadeh, literature search, data analysis, and revision of the manuscript.

Conflict of Interest: There is no conflict of interest to declare.

Funding/Support: This study was supported by the research affairs department of Shiraz University of Medical Sciences. This study was approved by ethical committee of the Shiraz University of Medical Sciences (No. EC-P-93636513).

\section{References}

1. Arvaniti V, D’Amico G, Fede G, Manousou P, Tsochatzis E, Pleguezuelo $\mathrm{M}$, et al. Infections in patients with cirrhosis increase mortality fourfold and should be used in determining prognosis. Gastroenterology. 2010;139(4):1246-56. doi: 10.1053/j.gastro.2010.06.019. [PubMed: 20558165] 1256 e1-5.

2. Gustot T, Durand F, Lebrec D, Vincent JL, Moreau R. Severe sepsis in cirrhosis. Hepatology. 2009;50(6):2022-33. doi: 10.1002/hep.23264. [PubMed: 19885876].

3. El-Shabrawi MH, El-Sisi O, Okasha S, Isa M, Elmakarem SA, Eyada I, et al. Diagnosis of spontaneous bacterial peritonitis in infants and children with chronic liver disease: A cohort study. Ital JPediatr. 2011;37:26. doi: 10.1186/1824-7288-37-26. [PubMed: 21599998].

4. Song KH, Jeon JH, Park WB, Park SW, Kim HB, Oh MD, et al. Clinical outcomes of spontaneous bacterial peritonitis due to extendedspectrum beta-lactamase-producing Escherichia coli and Klebsiella species: a retrospective matched case-control study. BMC Infect Dis 2009;9:41. doi: 10.1186/1471-2334-9-41. [PubMed: 19361340].

5. Fernandez J, Navasa M, Gomez J, Colmenero J, Vila J, Arroyo V, et al. Bacterial infections in cirrhosis: epidemiological changes with invasive procedures and norfloxacin prophylaxis. Hepatology. 2002;35(1):1408. doi: 10.1053/jhep.2002.30082. [PubMed: 11786970]. 
6. Wong F, Bernardi M, Balk R, Christman B, Moreau R, Garcia-Tsao G, et al. Sepsis in cirrhosis: report on the 7th meeting of the International Ascites Club. Gut. 2005;54(5):718-25. doi: 10.1136/gut.2004.038679. [PubMed: 15831923].

7. Wheeler AP, Bernard GR. Treating patients with severe sepsis. $N$ Engl J Med. 1999;340(3):207-14. doi: 10.1056/NEJM199901213400307. [PubMed: 9895401].

8. Gabay C, Kushner I. Acute-phase proteins and other systemic responses to inflammation. $N$ Engl J Med. 1999;340(6):448-54. doi: 10.1056/NEJM199902113400607. [PubMed: 9971870].

9. Chinnock B, Afarian H, Minnigan H, Butler J, Hendey GW. Physician clinical impression does not rule out spontaneous bacterial peritonitis in patients undergoing emergency department paracentesis. Ann Emerg Med. 2008;52(3):268-73. doi: 10.1016/j.annemergmed.2008.02.016. [PubMed: 18433932].

10. Runyon BA, McHutchison JG, Antillon MR, Akriviadis EA, Montano AA. Short-course versus long-course antibiotic treatment of spontaneous bacterial peritonitis. A randomized controlled study of 100 patients. Gastroenterology. 1991;100(6):1737-42. [PubMed: 2019378].

11. Koulaouzidis A, El-Ramli R, Gasem J, Saeed AA. Leukocyte esterase reagent strips for spontaneous bacterial peritonitis: what now?. Ann Hepatol. 2008;7(3):255-6. [PubMed:18753994].

12. Moosa AA, Quortum HA, Ibrahim MD. Rapid diagnosis of bacterial meningitis with reagent strips. Lancet. 1995;345(8960):1290-1. [PubMed: 7746063].

13. Azoulay E, Fartoukh M, Galliot R, Baud F, Simonneau G, Le Gall JR, et al. Rapid diagnosis of infectious pleural effusions by use of reagent strips. Clin Infect Dis. 2000;31(4):914-9. doi: 10.1086/318140. [PubMed: 11049770].

14. Casey LC, Balk RA, Bone RC. Plasma cytokine and endotoxin levels correlate with survival in patients with the sepsis syndrome. Ann Intern Med. 1993;119(8):771-8. [PubMed: 8379598].

15. Roumen RM, Redl H, Schlag G, Zilow G, Sandtner W, Koller W, et al. Inflammatory mediators in relation to the development of multiple organ failure in patients after severe blunt trauma. Crit Care Med. 1995;23(3):474-80. [PubMed: 7874897].

16. Memis D, Gursoy O, Tasdogan M, Sut N, Kurt I, Ture M, et al. High C-reactive protein and low cholesterol levels are prognostic markers of survival in severe sepsis. J Clin Anesth. 2007;19(3):186-91. doi: 10.1016/j.jclinane.2006.10.008. [PubMed: 17531726].

17. Thijs LG, Hack CE. Time course of cytokine levels in sepsis. Intensive Care Med. 1995;21 Suppl 2:S258-63. [PubMed: 8636533].

18. Povoa P, Almeida E, Moreira P, Fernandes A, Mealha R, Aragao A, et al. C-reactive protein as an indicator of sepsis. Intensive Care Med. 1998;24(10):1052-6. [PubMed: 9840239].

19. Yentis SM, Soni N, Sheldon J. C-reactive protein as an indicator of resolution of sepsis in the intensive care unit. Intensive Care Med 1995;21(7):602-5. [PubMed: 7593905].
20. Smith RP, Lipworth BJ, Cree IA, Spiers EM, Winter JH. C-reactive protein. A clinical marker in community-acquired pneumonia. Chest. 1995;108(5):1288-91. [PubMed: 7587431].

21. Park WB, Lee KD, Lee CS, Jang HC, Kim HB, Lee HS, et al. Production of C-reactive protein in Escherichia coli-infected patients with liver dysfunction due to liver cirrhosis. Diagn Microbiol Infect Dis. 2005;51(4):227-30. doi: 10.1016/j.diagmicrobio.2004.11.014. [PubMed: 15808312].

22. Le Moine O, Devière J, Devaster J, Crusiaux A, Durand F, Bernuau J, et al. Interleukin-6: an early marker of bacterial infection in decompensated cirrhosis. J Hepatol. 1994;20(6):819-24.

23. Foreman MG, Mannino DM, Moss M. Cirrhosis as a risk factor for sepsis and death: analysis of the National Hospital Discharge Survey. Chest. 2003;124(3):1016-20. [PubMed: 12970032].

24. Preto-Zamperlini M, Farhat SC, Perondi MB, Pestana AP, Cunha PS, Pugliese RP, et al. Elevated C-reactive protein and spontaneous bacterial peritonitis in children with chronic liver disease and ascites. J Pediatr Gastroenterol Nutr. 2014;58(1):96-8. doi: 10.1097/MPG.0000000000000177. [PubMed: 24051480].

25. American College of Chest Physicians/Society of Critical Care Medicine Consensus Conference: definitions for sepsis and organ failure and guidelines for the use of innovative therapies in sepsis. Crit Care Med. 1992;20(6):864-74. [PubMed: 1597042].

26. Caruntu FA, Benea L. Spontaneous bacterial peritonitis: pathogenesis, diagnosis, treatment. J Gastrointestin Liver Dis. 2006;15(1):51-6. [PubMed: 16680233].

27. Yuan LY, Ke ZQ, Wang M, Li Y. Procalcitonin and C-reactive protein in the diagnosis and prediction of spontaneous bacterial peritonitis associated with chronic severe hepatitis B. Ann Lab Med. 2013;33(6):44954. doi: 10.3343/alm.2013.33.6.449. [PubMed: 24205495].

28. Viallon A, Zeni F, Pouzet V, Lambert C, Quenet S, Aubert G, et al. Serum and ascitic procalcitonin levels in cirrhotic patients with spontaneous bacterial peritonitis: diagnostic value and relationship to pro-inflammatory cytokines. Intensive Care Med. 2000;26(8):1082-8. [PubMed: 11030164].

29. Kasztelan-Szczerbinska B, Slomka M, Celinski K, Serwacki M, Szczerbinski M, Cichoz-Lach H. Prevalence of spontaneous bacterial peritonitis in asymptomatic inpatients with decompensated liver cirrhosis - a pilot study. Adv Med Sci. 2011;56(1):13-7. doi: 10.2478/v10039-011-0010-6. [PubMed: 21536540].

30. Vieira SM, Matte U, Kieling CO, Barth AL, Ferreira CT, Souza AF, et al. Infected and noninfected ascites in pediatric patients. J Pediatr Gastroenterol Nutr. 2005;40(3):289-94. [PubMed:15735482].

31. Kwon JH, Jang JW, Kim YW, Lee SW, Nam SW, Jaegal D, et al. The usefulness of C-reactive protein and neutrophil-to-lymphocyte ratio for predicting the outcome in hospitalized patients with liver cirrhosis. BMC Gastroenterol. 2015;15:146. doi: 10.1186/s12876-015-0378-z. [PubMed: 26498833]. 